\title{
THE ROLE OF MEXICO IN THE FIRST WORLD OIL SHORTAGE: 1918-1922, AN INTERNATIONAL PERSPECTIVE*
}

\author{
MARÍA DEL MAR RUBIO \\ Universitat Pompeu Fabra ${ }^{\mathrm{a}}$
}

\begin{abstract}
RESUMEN
En 1921 México producía un cuarto del petróleo mundial, siendo el segundo mayor productor en el mundo, pero para 1930 ya sólo representaba el 3 por cien de la producción. Hasta la fecha la mayor parte de la discusión se ha basado en los hechos acaecidos en México para explicar el declive de la industria petrolera, poniéndose muy poca atención en los acontecimientos de la industria petrolera en otros lugares, salvo en Venezuela. Prácticamente ningún esfuerzo se ha dedicado a entender las razones del auge, ignorando así los cambios masivos que tuvieron lugar en la industria petrolera durante la Primera Guerra Mundial y la inmediata posguerra, y sobre todo, olvidando la crisis energética que se produjo entre 1918 y 1921. Estos eventos son cruciales a la hora de comprender el primer auge de la

* I am grateful to Marco Palacios and Pilar Gonzalbo for their support while at COLMEX, and to German Rojas for his support while at ITAM. Thanks also to the staff of the Biblioteca del Banco de México and Biblioteca Central de Petróleos Mexicanos for their assistance. The comments on earlier versions of this paper made by participants of seminars at Universidad Carlos III in Madrid, the ITAM and the Universidad Autónoma Metropolitana in Aztcapotzalco were very helpful and encouraging. Financial support from the LSE and the AGAUR are also acknowledged. At the time of publication financial support was provided by the «Juan de la Cierva» research fellowship associated to the research project «Imports and economic modernisation in Latin America 1870-1960» (BEC2003-00190). The usual disclaimers apply.

${ }^{a}$ Economics and Business Department. Carrer Ramon Trias Fargas, 25, Barcelona 08005. mar.rubio@upf.edu.
\end{abstract}


industria petrolera mexicana y sientan las bases para comprender mejor el posterior súbito declive.

Palabras clave: oferta mundial de petróleo, México, I Guerra Mundial, crisis energética

\begin{abstract}
In 1921 Mexico produced a quarter of the world's petroleum, making the country the second largest producer in the world, but by 1930 it only accounted for 3 per cent of production. To date, the debate surrounding this decline has relied mainly on events taking place in Mexico. Very little attention has been paid to developments elsewhere in the petroleum industry, except in Venezuela. Practically no attention has been paid to the reasons for the rise of oil output in Mexico. The massive changes which took place in the petroleum industry during the Great War years and its aftermath and especially the shortage of oil which occurred on world markets between 1918 and 1921 have been neglected. These events are crucial in order to understand the initial rise of the Mexican oil industry and help to understand the subsequent sudden decline.
\end{abstract}

Keywords: world petroleum supply, Mexico, First World War, energy shortage JEL Classification: N700, N400, N560

\title{
INTRODUCTION
}

In 1921 Mexico produced a quarter of the world's oil, making the country the second most important producer in the world, but by 1930 it only accounted for 3 per cent of world production. In 1938 the petroleum industry was nationalised by the Mexican government and it took over fifty years to regain the level of output of 1921. Two main lines of arguments have been used in order to explain the rapid decline of the Mexican oil industry during the 1920s. The first argues that the decline was the result of the institutional change caused by the Mexican Revolution. The second hypothesis maintains that Mexico simply ran out of oil deposits that could be extracted at competitive costs given technology, prices and competing sources. Some authors have argued that both hypotheses are true. The problem is that the discussion has relied mostly on events taking place in Mexico, using sources and data exclusively relating to Mexico. Very little attention has been paid to developments in the petroleum industry elsewhere, except in Venezuela. Practically no attention has been paid to the reasons for the sudden rise 
of oil output in Mexico. The massive changes which took place in the petroleum industry during the Great War years and its aftermath and especially the shortage of oil which occurred on world markets between 1918 and 1921 have been neglected. These events are crucial in order to understand the initial rise of the Mexican oil industry and help to understand the subsequent sudden decline.

The first section of this paper reviews the literature debate, revealing how little attention has been paid to the growth of the industry and how much attention has been concentrated on events within Mexico. The second section steps out of Mexico in order to show the extensive changes taking place in the oil industry worldwide during the First World War and its aftermath, including the surge in demand and the awakening of nationalism worldwide regarding the exploitation of oil resources. For example, while in 1914 only 3 per cent of the tonnage shipped in the world was on oil-fuelled ships, the share grew to 15 per cent in 1920, 31 per cent in 1924 and by 1934 almost half of the world tonnage was on board oil-fuelled vessels.

The intense growth of demand for petroleum products was not followed by an equal growth in supply. The distortions introduced by the War, the Soviet Revolution, the cold winters of the end of the 1910s, plus the War effort produced the first petroleum shortage of the $20^{\text {th }}$ century. New quantitative evidence illustrates these facts showing production and price figures. Section 3 reveals the importance of Mexican oil at this time of shortage again making use of new quantitative evidence of the importance of Mexican oil in supplying world markets. Section 4 deals with the sudden decline of the Mexican petroleum industry departing from the depiction of the rise of the industry provided in earlier sections. The shortage ended as did the crucial role played by Mexico as a major oil supplier. What did not end were the uncertainties in the world petroleum industry. The scenario for a worldwide oil rush was set at the end of the War. Oil was sought out in more countries during the second half of 1920s than ever before yet the nationalism awakened during the War made it difficult for companies to secure new exploration contracts and nothing could guarantee that previously signed agreements were to be honoured. It is not heroic? to presume that the uncertainties in the world's petroleum industry had a negative impact on the Mexican oil industry. Not only had the U.S. lost interest in Mexican oil as a result of the discovery of extensive domestic supplies, but also the country's industry entered the 1920s with a new active policy for securing reserves elsewhere. The conclusions summarise the main findings of this paper.

\section{THE RISE AND FALL OF THE EARLY MEXICAN OIL INDUSTRY: A REVIEW}

The development of the oil industry in the South of the United States and the similarity of its coastal area to that of northern Mexico attracted worldwide atten- 
tion in the first two decades of the $20^{\text {th }}$ century. A long dictatorship, that of Porfiri Díaz (1876-1911), brought political stability and legal facilities which encouraged foreign investors to explore the country's oil ${ }^{1}$. Mexico started commercial oil production in 1901, although it took almost a decade to produce significant amounts. In the following decades hundreds of oil companies were organized to exploit the Mexican subsoil ${ }^{2}$. Between 1911 and 1921 the foreign enclaves, especially the oil industry, «stood out as islands of prosperity in the sea of destitution caused by the Mexican Revolution» ${ }^{3}$. In the midst of coups, revolutions, counter-revolutions and a general state of civil war, the oil companies managed to turn Mexico into the world's main oil exporter and its second largest producer.

At its peak, Mexico produced a quarter of the world's oil but ten years later, in 1931, it only accounted for 3 per cent of world production. As can be observed in Figure 1, it took over fifty years to regain the output level of 1921. Two main lines of arguments have been used in order to explain the rapid decline of the Mexican oil industry in the 1920s. The first argues that the decline was the result of the institutional change caused by the Mexican Revolution. The second hypothesis maintains that Mexico simply ran out of oil. Some authors have argued that a fatal combination of both provides the explanation for the rapid decline of the Mexican oil industry.

Those who favoured the institutional explanation focused on the increasingly tense relationships between the post-revolutionary Mexican governments and the foreign companies operating in the country ${ }^{4}$. The issue came down to two elements: the stability of agreements and the question of sovereignty and ownership ${ }^{5}$. From

1 The following works provide a good insight into the economic history of the early part of the 20 ${ }^{\text {th }}$ century: Cárdenas (1992-1994); Colegio de México (1960); Colegio de México (1965); Haber (1989); Reynolds (1970).

2 Some 447 companies existed in Mexico in 1919, but only 24 produced in exportable quantities, Rippy (1972), pp. 137, footnote 18. Yet from 1900 to 1919 three firms controlled almost all Mexican oil production: the first entrant, Waters-Pierce Oil Company of St. Louis (a Standard Oil affiliate) and two initially independent companies, Huasteca owned by Doheny, a U.S. investor who in 1932 sold it to Jersey Standard, and El Aguila (partially sold to Dutch/Shell in the 1920s) owned by the British engineer Weetman Pearson (known as Lord Cowdray). Exports, nevertheless, were controlled by the large marketing firms: Jersey Standard (U.S.) and Dutch/Shell (Dutch and British) to which both independent firms sold their oil. In 1938, the Mexican government expropriated by executive decree the property of seventeen foreign-owned oil companies without compensation. Many articles deal with the dominant players at world level but also within the Mexican context, see Wilkins (1974), Haber et al. (2004) and especially Brown (1985; 1993).

3 Knight (1992), p. 295. See also Thorp (1998, p. 68) and Reynolds (1970) who initially demonstrated this.

4 The first chapters of the following books provide a good review of the initial stages of the Mexican oil industry: Grayson (1980); López Portillo (1975); Menéndez (1958); Owen (1975); PEMEX (1988), vol. 1, and Chapter 8 in Rippy (1972). On Mexican government relations with the companies, see the first chapter of Bermudez (1963) and also Baldridge (1987).

5 Yergin (1991), p. 232. 
FIGURE 1

MEXICAN OIL PRODUCTION, 1901-2000 (DETAILED FOR 1901-1938)

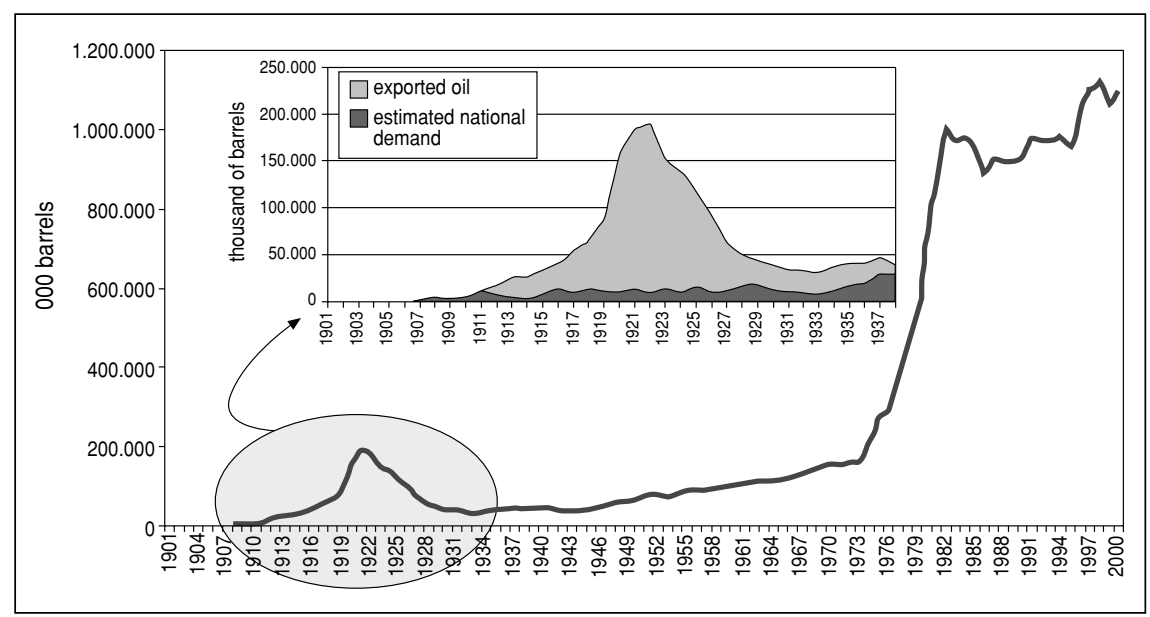

Sources: elaborated using oil production data 1901-1992: México. Instituto Nacional de Estadística Geografía e Informática (INEGI) (1994), cuadro 11.1, p. 559. Estimated national demand for oil obtained by subtracting exports volume from total production. Exports of oil sources: 1991-1936: México (1937 December); 1937: Haber et al. (no published); 1938-1939: PEMEX (1952) p. 47. Worls's production from American Petroleum Institute (1937).

1884 to the enactment of the Mexican Constitution of 1917 , concessions for the exploitation of mineral deposits were freely granted to foreign individuals and companies and there were no restrictions on the sale of oil fields by natives to foreigners. Article 27 of the 1917 Constitution returned to the several centuries old legislation of the Spanish mining code, making all subsoil wealth the property of the nation. Although, in principle, the new law could not have retroactive effects, various other decisions taken by successive Mexican governments - regulations, tax hikes, the creation of Federal reserves - fuelled continuing conflicts with oil companies and led to diplomatic protests by the Governments of the United States, France and Great Britain over the next decade ${ }^{6}$. In addition to the threat of arbitrary deprivation of vested rights, the companies also had difficulties with the workers in the oil fields who became increasingly organized after the Revolution ${ }^{7}$. From this description it follows that the increasing nationalist tendencies of the successive post-revolutio-

${ }^{6}$ Federal Reserves implied the retention of land for further exploration and potential exploitation by the state. For a discussion of Federal Reserves see López Portillo (1938). For a short historical overview of events see Haber et al. (2003).

${ }^{7}$ Novelo (1991); Ramírez Heredia (1979); Adleson (1992). 
nary Mexican governments paralysed exploration and reduced production by foreign companies, leading to the early decline of the Mexican oil industry.

Other authors reject the importance of the institutional factors in the decline of the Mexican oil industry. For instance, Thorp (1989) argued that the potential threat posed by the 1917 Constitution was not taken very seriously in the 1920s. Haber et al. (2003) also argued that calls for intervention and punitive sanctions against Mexico by the American oil companies and the corresponding protests by the U.S. State Department on their behalf, should not be taken as evidence that the oil companies were genuinely threatened, but should instead be understood as a signal by the U.S. government that it would enforce American property rights. The U.S. Congress was not the oil companies' only recourse; the companies, it has been argued, could also withhold output and deny the Mexican government crucial tax revenues. Figure 2 shows the importance of petroleum taxes for the Mexican government. At a maximum level they accounted for almost 20 per cent of the fiscal income of the government.

FIGURE 2

PETROLEUM TAXES vs. OTHER TAXES (MEXICO 1901-1937)

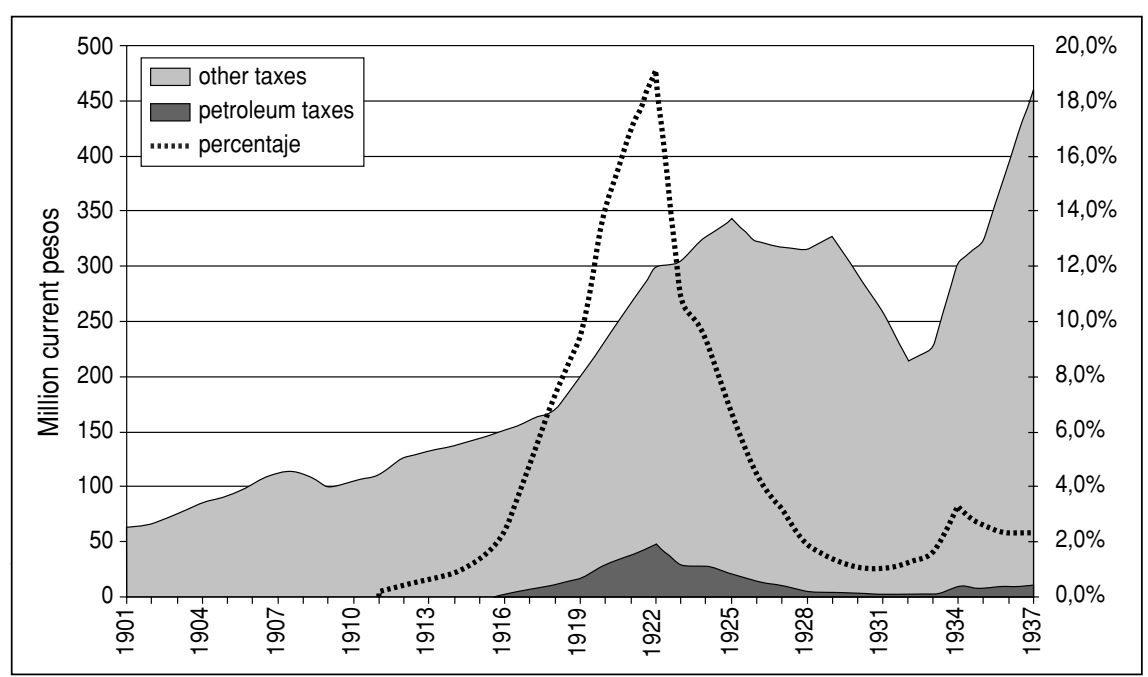

Sources and notes: Left axis in millkion of current pesos; percentage of oil taxes in total fiscal income on the right axis. Own elaboration from data on oil taxes from: 1912-1920: México (1925); 1920-1933: México. Secretaría de Hacienda y Crédito Público. Departamento de Impuestos Especiales. Sección de Petróleo (1936a); 1934-1936: Ibid. plus royalty payments from México. Secretaría de Patrimonio Nacional (1963); 1937: México. Secretaría de Hacienda y Crédito Público. Dirección General Técnica de Ingresos. Oficina de Investigaciones Económicas (1938), p. 387. The data on total fiscal income from: 1901-1911 and 1925 onwards: México. Instituto Nacional de Estadística Geografía e Informática (INEGI) (1994); 19121924: It is possible to infer government income for 1912 and 1918 from the data provided by Wilkie (1967), Table I.II, p. 28. The gaps were then filled linearly. 
On the side of the companies, it seems, increases in taxes had only a minor impact on corporate rates of return. In fact, it has also been claimed by Haber $e t$ al. (2003), the companies continued to explore and invest well after output began to fall. They simply could not find sources of petroleum that could be extracted at a reasonable price using existing technology. Mexico's petroleum industry went into decline because Mexico ran out of oil.

Actually, Mexican scholars were the first to advance the geological explanation - the exhaustion of Mexican oil fields - in the 1930s. Most Mexicans did not view the petroleum industry developed by foreigners as an unmitigated blessing. As reported in Brown (1993), the Mexicans accused the wealthy companies of financing reactionary political movements, dividing and repressing the workers, extracting the nation's non-renewable resources and subordinating domestic needs to the international interest, making huge profits in the process. In this line, Mexicans had their own justification for the decline of the oil industry. From the Mexican point of view, as reported in Manterola (1937), the companies exhausted oil fields in order to cope with demand. The so-called limitless capacity of Mexican oil fields turned into fears of exhaustion in the early 1920s. More capital would have been invested in further development of the Mexican industry if Mexican oil fields had not been over-exploited beforehand ${ }^{8}$. The general agreement among Mexican scholars was that oil reserves could not be exploited in a sensible manner when there were several companies involved. According to this view, fields were being totally exhausted under private exploitation. Oil was such an important element for the Mexican economy and society that individual interests should not drive its exploitation. «Oil should not be extracted for profit but for the salvation of a society» claimed some scholars ${ }^{9}$. In addition, the companies were accused of hiding profits. According to Silva Herzog (1938, pp. 447-457), the companies were distorting information about their profit margins in order to evade taxes. They were not only using up Mexican oil, but also failing to pay any compensation.

A combination of the institutional and the geological explanations has also been put forward. Both problems arose almost simultaneously: salt water started to enter big Mexican production wells as early as 1918, only few months after the new Constitution was passed. According to Yergin (1991, p. 232):

«The salt water was very bad news - it meant the beginning of a decline in oil output. The problem could have been conquered with more capital,

${ }^{8}$ At least that is the Mexican view expressed by several authors in the monthly journal of the National Union of Mexican Economists (Revista de Economía) quoted below. It is also the view of Sangines Villavalva (1938 March).

9 The following sentences are mainly from López Portillo (1938). Identical views are expressed by Sangines Villavalva (1938 March). 
better technology and new exploration. But in the midst of the revolutionary turmoil, the foreign companies were loath to step up their investment».

While the companies and the government were settling their disputes in Mexico, Venezuela captured the attention of the oil companies. A huge production per well in the Maracaibo basin after 1922, low transport costs ${ }^{10}$, low political risk factors (an all-powerful dictator and a docile labour force) and the best petroleum law in the world combined to give Venezuela an important international cost advantage. As Brown (1985), put it «the oilmen shifted their interest from Mexico to Venezuela because of the loss of Mexican oil's competitiveness, a loss reinforced but not caused by revolutionary nationalism». From this perspective, geological and institutional factors combined to the detriment of the Mexican oil industry.

The different explanations are based on different kinds of evidence. The institutional explanation is supported primarily by the diplomatic correspondence between the companies their respective governments and the Mexican authorities. It also made use of the analysis of the legal changes made by the latter. The exhaustion theory, supported by the Mexican scholars, was encouraged by nationalistic feelings and the immediate evidence of the day: sanding-up of wells and sinking production. The combined explanation came to light when companies' records became available. It was then possible to add some patchy quantitative evidence to the debate, emphasizing some of the economic determinants. Nevertheless, as Haber et al. (2003) argued, these studies «do not bring to bear much in the way of systemically retrieved and analysed data». Their retrieval and analysis of additional data on average taxes, corporate profits, capital stocks and flows supports the geological explanation.

Regardless of the nature of the evidence used, all the explanations have a common feature: the narrow focus on Mexico. Very little attention has been paid to developments in the petroleum industry elsewhere, except in Venezuela. Practically no attention has been paid to the reasons for the sudden rise in oil output in Mexico. The rise is almost seen as an inevitable fact. The massive changes taking place in the petroleum industry worldwide during the Great War and the early 1920s are neglected. Above all, the shortage of oil suffered by world markets between 1918 and 1921 is ignored. These are crucial events in an understanding of both the rise of the Mexican oil industry and its subsequent sudden decline.

${ }^{10}$ Most of the fields were situated on the Eastern shore of Lake Maracaibo. Lake and ocean tankers were used which were able to transport huge amounts of crude at very low cost. 


\section{THE EARLY PETROLEUM INDUSTRY AND THE OIL SHORTAGE OF 1918-1921}

The First World War was responsible for the rapid maturity of the petroleum industry. Just prior to the war, both the U.S. and Great Britain began the conversion of their naval fleets from coal to oil-fuelled vessels. Not only did petroleum propel the newest and fastest warships, but it also provided fuel for such military innovations as the submarine, the tank and the airplane. As DeNovo (1956) reminds us, oil-fed trucks and automobiles played a military role during wartime, while petroleum was even a basic constituent of TNT.

The stimulus experienced by industrial and transport technology during the war enormously increased the post-war demand for petroleum products. The merchant fleet and the railways (especially those of the Americas) started the switch to oil-fuelled engines. According to the data of the American Petroleum Institute (1937) and the Lloyd's Register of Shipping, in 1914 only 3 per cent of the tonnage shipped in the world was on oil-fuelled ships (see Figure 3). The share grew

FIGURE 3

WORLD'S TONNAG TYPE OF SHIP ENGINE AND SHARE OF TONNAGE ON OIL-BURNING SHIPS ONTOTAL TONNAGE

(Tons -left axis- and percentages -rights axis-)

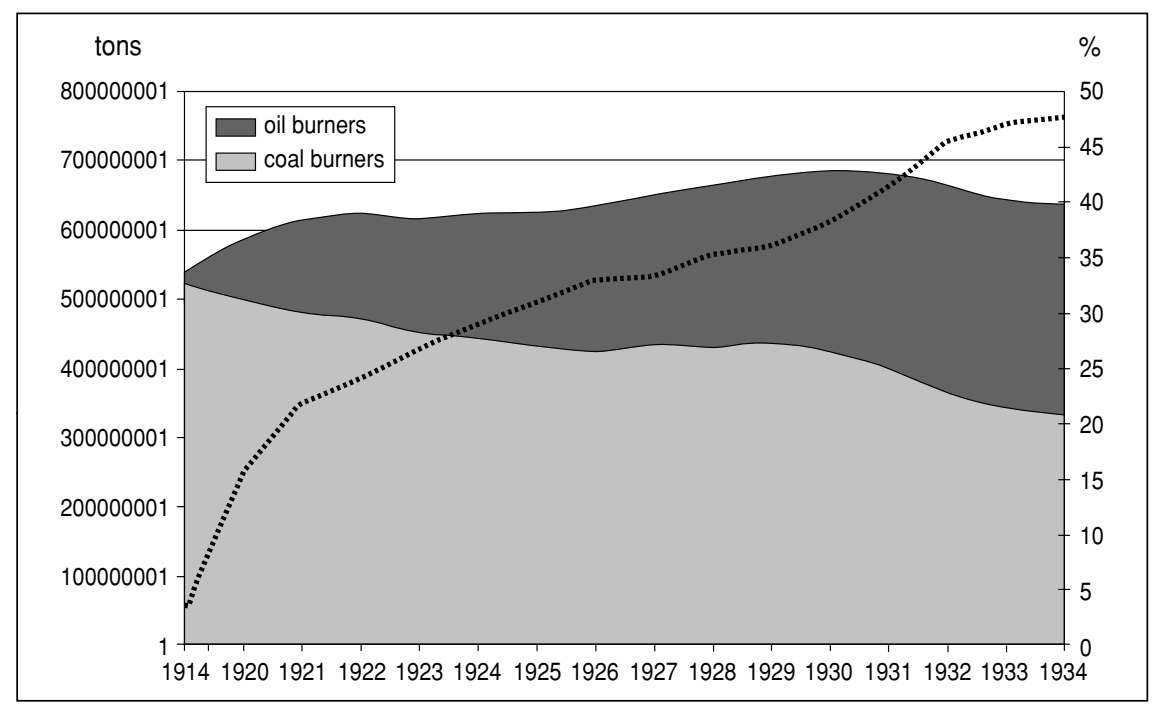

Sources and notes: Elaborated from ddata Americam Petroleum Institute (1937), p. 30 for tonnage in oil burning ships. World's total the Lloyd's Register of Shipping). Tonnage of Oil-burning ships, exclusive of Army, Navy and other govermment oil burners. 
to 15 per cent in 1920, 31 per cent in 1924 and by 1934 almost half of the world's tonnage was on board an oil-fuelled vessel. According to the same sources, in the case of the U.S. flag fleet, more than half of the cargo was shipped using oil as locomotive fuel; the exact figures are 62 per cent by 1924 and 71 per cent in 1934, in contrast to 15 per cent in 1914.

The increasing number of motor vehicles (cars, trucks and buses) also demanded more oil. According to the statistics of the American Petroleum Institute (1937) and estimates by Yergin (1991), the number of registered vehicles in the U.S. rose from 1.8 million in 1914 , to 10.4 million in 1921 . The 26.5 million registered vehicles of 1929 represented 78 per cent of the estimated number of motorcars in the world.

Industry also required more oil worldwide. The use of fuel oil and diesel engines as prime movers and as electricity generators in places with either few hydraulic resources or little coal, together with the necessary lubricants for the machinery, also increased the demand for petroleum products in the 1920s. The U.S. Department of Commerce (1931) estimated that by the end of the 1920s and excluding oil used by oil companies, approximately 37 per cent of all world petroleum was used to produce gasoline, 5 per cent for lubricants, while kerosene, the major market in the early days of the industry, only used 8 per cent of all petroleum produced. Practically all the remaining half was used as gas or fuel oil. This fuel oil was used principally for bunkering ships and as locomotive fuel, for which coal, supplied largely by Great Britain, had been formerly used. These were precisely the primary uses of Mexican oil during the 1920s: fuel for steam and diesel ships and fuel oil for homes and industry ${ }^{11}$. Nevertheless, the contribution of oil to the world energy supply at this time must not be exaggerated. In 1925, solid fuels supplied 82.9 per cent of the energy consumed, liquid fuels 13.2 per cent, natural gas 3.2 per cent and hydroelectric power 0.7 per cent [see Darmstadter et al. (1971)].

Among other consequences of the War, a spirit of nationalism was awakened in all countries which involved the ideas of self-determination, self-preservation and national security. The latter idea immediately suggested the importance of conserving the natural resources and raw materials of any given country. These considerations led to the adoption of governmental programs of exclusion or discrimination against foreigners, together with the development of their own natural resources by their own citizens ${ }^{12}$. In form, such protection was either legislative such as, for example, the enactment of restrictive laws; contractual, as in the case of an agreement between the Government and its citizens for the working of

\footnotetext{
11 Brown (1985), p. 367.

12 This is the interpretation made by the U.S. Trade Commission (1923) regarding developments in the world of oil producing countries.
} 
large areas to the exclusion of aliens; or administrative, as when the granting of concessions was left to the discretion of an executive officer who favored the nationals of his own country. In this context, Mexico's increasing nationalism was not unique, but rather the norm among oil producing countries in the early 1920s.

The surge in demand was not coupled with an equally intense growth in the supply of oil. For the first years of the War demand was well ahead of supply. Before the War, the U.S. produced about 60 per cent of the petroleum produced in the world ${ }^{13}$. The second largest producer was Russia, with 20 per cent of world production or, in other words, about half the production outside the U.S. In fact, from 1898 to 1901, Russia led the world in petroleum production. The remaining production was more or less distributed in shares of 2 to 5 per cent of world production between Mexico, the Dutch East Indies, British India, Rumania and what became Poland after the war. Figure 4 shows world oil production between 1900 and 1936 by main producer countries.

FIGURE 4

WORLD'S PETROLEUM PRODUCTION MAIN PRODICERS, 1900-1936 (Million barrels)

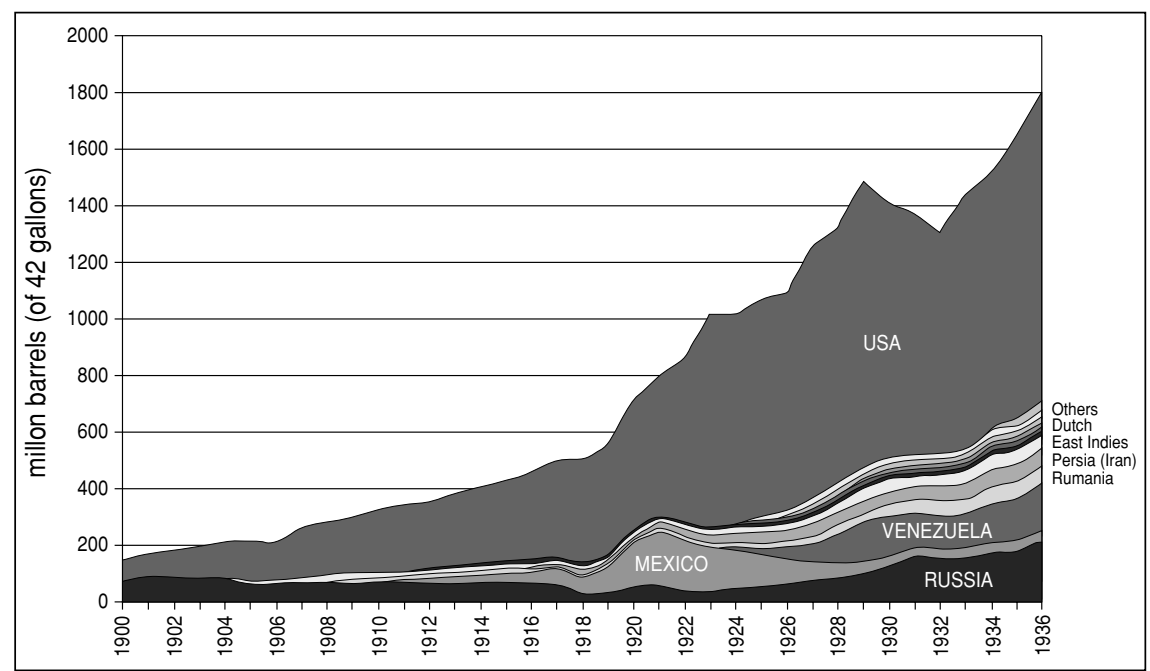

Sources and notes: Shares correspond to the USA. Data from American Petroleum Institute (1937).

${ }^{13}$ Unless otherwise stated, all data on production of petroleum used in the paper come from the American Petroleum Institute (1937) pp. 56-57. 
The collapse of Russian production started the shortage of oil of 1918-1921. As mentioned by Yergin (1991), during the War oil became the «blood of victory». Unlike Rumania and Poland and despite the shortage of manpower during the War years, Russia managed to keep its petroleum production running and maintain its position as the second largest world producer. What hampered Russia's production was the Bolshevik revolution. Both Baku and Grozny (the main oil producing regions) changed hands twice between 1918 and 1920 and, according to U.S. Department of Commerce (by W. A. Ottis) (1924), during the fighting much of the oil property was destroyed and a large number of the remaining operatives were killed. As a consequence, Russian production halved, and did not recover its prerevolution levels until 1926. This can be seen in Figure 5 which shows the supply of oil outside the United States for the period 1900-1936.

Having lost all its domestic oil supplies, Europe was dependent on its Asian oil supplies (Dutch East Indies, Persia and British India) all of which produced insufficient amounts to satisfy European needs and were too remote. European markets became totally dependent on the U.S.

The collapse of Europe's main sources of petroleum coupled with a succession of cold winters $\left(1918,1919\right.$ and 1920 were some of the coldest of the $20^{\text {th }}$ century on both sides of the Atlantic) and the final War effort. In addition, the awakening

FIGURE 5

WORLD'S PETROLEUM PRODUCTION OUTSIDE THE USA, 1900-1936 (Million barrels)

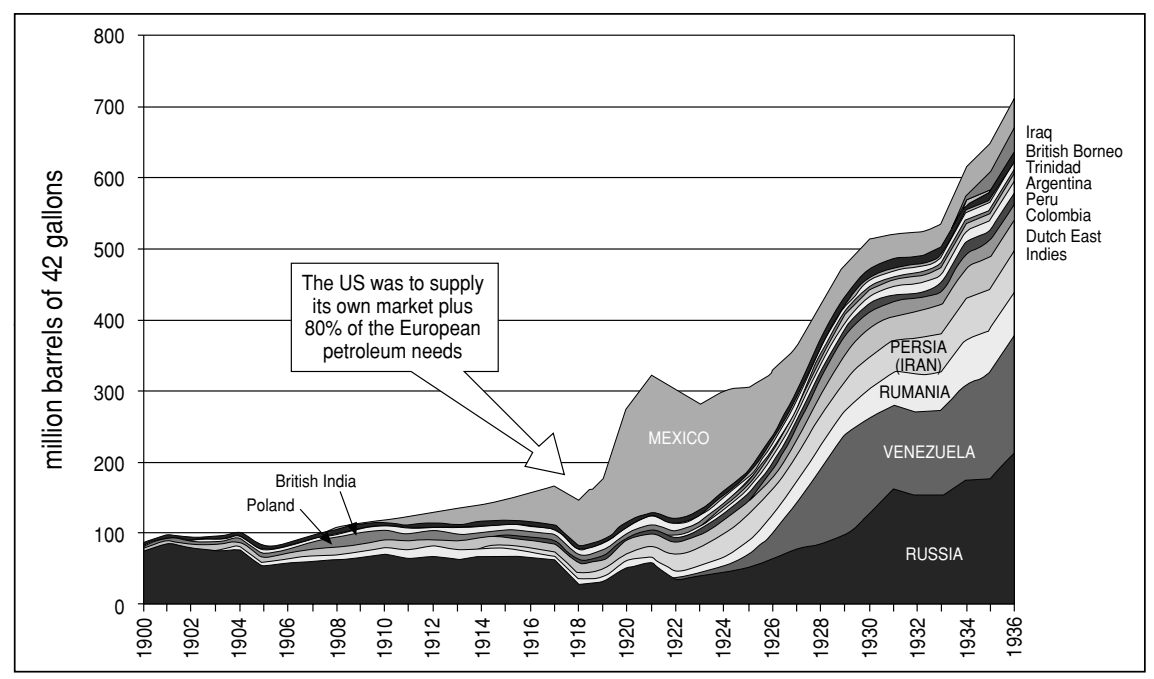

Source: American Petroleum Institute (1937). 
of nationalism over the exploitation of natural resources created increasing difficulties for the private companies for obtaining new petroleum concessions.

In fact, Mexico was neither the first nor the most radical country in the adoption of nationalistic positions in this respect, as demonstrated by a U.S. Federal Trade Commission (1923) report on petroleum ownership. In Russia, all movable or immovable property belonging to the petroleum industry, including the Caspian commercial fleet, was declared property of the State by decree in June 1918. In addition, trading in oil was declared a State monopoly, production and distribution being placed under the general management of the chief petroleum committee of the fuel department of the supreme council of national economy. Agitation for nationalization of the petroleum industry also heated up in Rumania, the second largest producer in Europe before the War. In November 1918, large land areas were expropriated from both native and foreign owners and resold to peasants, the Government reserving the subsoil rights. Uncertainty regarding further steps towards nationalization of the Rumanian oil industry remained for most of the first half of the 1920s.

The Dutch and the British also obtained mutually exclusive rights in their overseas dominions. In practice, the Dutch Shell group had secured a quasi-monopoly in the East Indies, while the British Government adopted a policy of complete exclusion of aliens regarding the oil fields of British India, particularly those of Burma. Anglo-Persian also held almost exclusive rights in Persia.

It was not any easier to obtain new oil rights in Latin America. Argentina was the first Latin American country to establish a national oil company, YPF (1907), and one of the first to pass strict legislative measures in order to limit the activities of private oil companies [see Philip (1982)]. From 1919 and during the early 1920s, both Colombia and Ecuador tried (but mostly failed) to enforce petroleum laws inspired in the Mexican legislation. Despite several modifications to the original laws, the foreign companies argued that the legislation of both countries was far from satisfactory for their interests. According to Wilkins (1974), in Peru and Bolivia the problems were not so much legislative over property and concessions, as fiscal. Long running conflicts regarding tax evasion and fraud affected the development of oil production in both countries. Therefore, it is clear that the very few countries to offer open door policies, such as Venezuela, Canada, Poland, Egypt or South Africa were exceptional among the oil producing countries of the early 1920s.

The supply problems led to the creation of the Inter-Allied Petroleum Conference which was established in February 1918. Its objective was to pool, coordinate and control all oil supplies and tanker shipping as well as the introduction of convoys as an antidote to German U-boats in an attempt to solve the Allies' oil supply problems for the rest of the war. Mexican oil was to play a major role at this time of shortage. 


\section{THE ROLE OF MEXICO IN THE FIRST OIL SHORTAGE}

The Inter-Allied Petroleum Conference was also set up in response to domestic American energy problems. According to Yergin's (1991) estimates, the U.S. was serving its own demanding market plus 80 per cent of the European requirement for oil. By 1918 the surging demand for American oil began to reach the limit of available supplies. The gap between available domestic supplies and the surging demand was bridged by using up inventories and by importing more oil from Mexico. Even when imports from Mexico trebled between 1918 and 1921, U.S. petroleum inventories continued to fall month after month for most of those three years as shown in Figure 6. Average crude oil prices at well head, which had doubled in the U.S. from the beginning of the War, would jump another 50 per cent in the two years after the armistice (see Figure 8 below).

The importance of imports from Mexico in those years should not be underestimated. The shrinkage of Russian production implied that Mexico was to produce more than half the oil outside the U.S. from 1919 to 1923. In addition, Mexico was the only country from which the U.S. imported crude oil until 1921 and in 1925 it still represented 89 per cent of all U.S. imports of crude oil. It could be argued, however, that imports never accounted for a big share of the total U.S. oil supply; at their peak, imports accounted for a fifth of total U.S. supply. Yet

FIGURE 6

PETROLEUM INVENTORIES IN THE USA 1918-1921 (END OF THE MONTH)

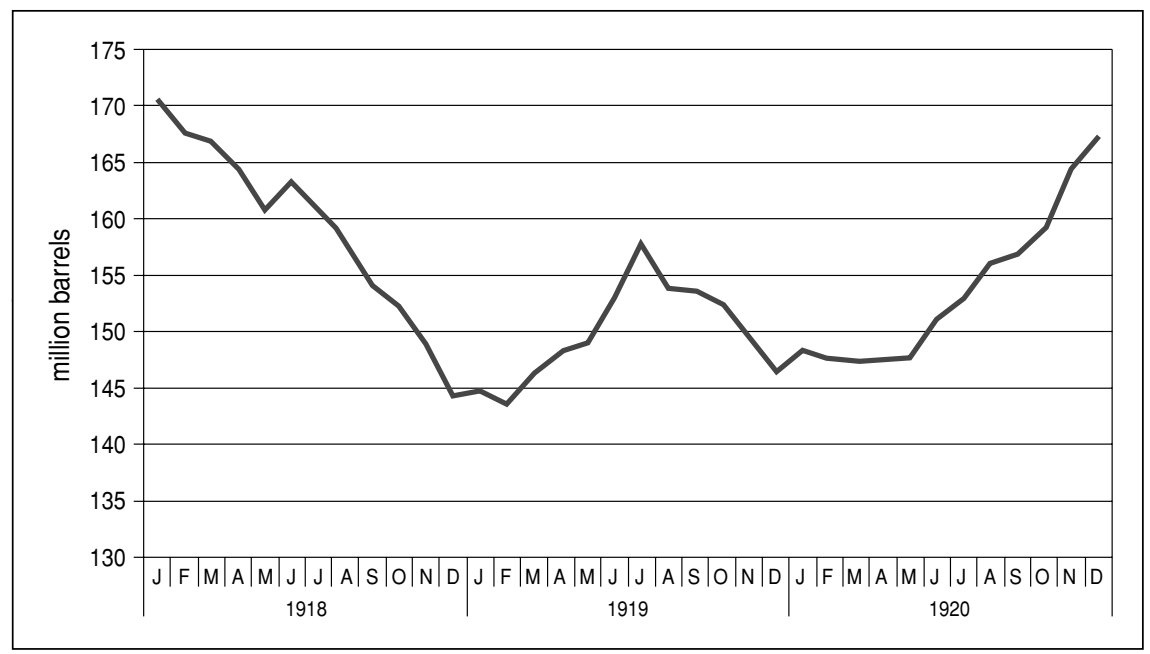

Source: US inventories of oil from NBER )2003) 
Mexico contributed to the oil supply of the U.S. as much as any of the domestic producing states. In fact, the Mexican state of Veracruz was the principal individual «state» contributing to the U.S. total oil supply. As can be seen in Figure 7, by 1921 the Mexican state of Veracruz produced more than any of the biggest domestic oil producers of the time (California, Oklahoma and Texas) for the U.S. market

Moreover, Mexican fields were better located than the main U.S. domestic fields to supply the cities of the Atlantic coast where ships were waiting to be loaded with materials for Europe. Domestically produced petroleum had a long way to travel to the East coast. From California the options were either to ship the oil via the Panama Canal or to transport by rail as the West coast was not connected by pipelines with the rest of the country. Oklahoma had no access to sea transport and had to make use of pipelines and rail and most Texan oil went to the Gulf Coast first and was then shipped to the Atlantic refineries. Mexican oil fields, by contrast, were very close to the Gulf and crude could be shipped immediately.

Indeed, the shortage of oil was felt worse on the Atlantic Coast. While it is true that the average price of oil at well head paid in the U.S. rose from \$0.64 in 1914 to $\$ 3.07$ in 1920 , it is also true that the price rises where much bigger on the East

FIGURE 7

OIL IMPORTS vs. DOMESTICALLY PRODUCED OIL THE USA, 1914-1929

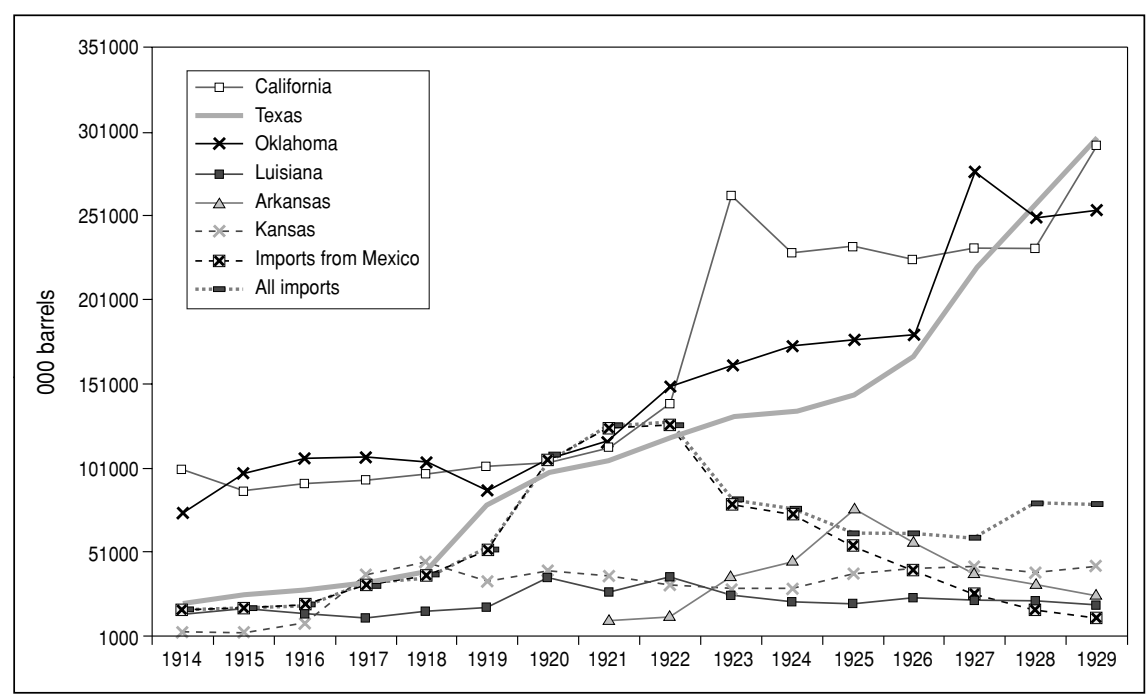

Sources: American Petroleum Institute (1937) pp. 62-63 for US production by state and p. 208 for imports of crude oil into the US by country of origin. 
FIGURE 8

AVERAGE PRICES, LACATION OF OIL PRODUCTION AND PRICE OF OIL AT WELLHEAD IN THE USA AT 1920

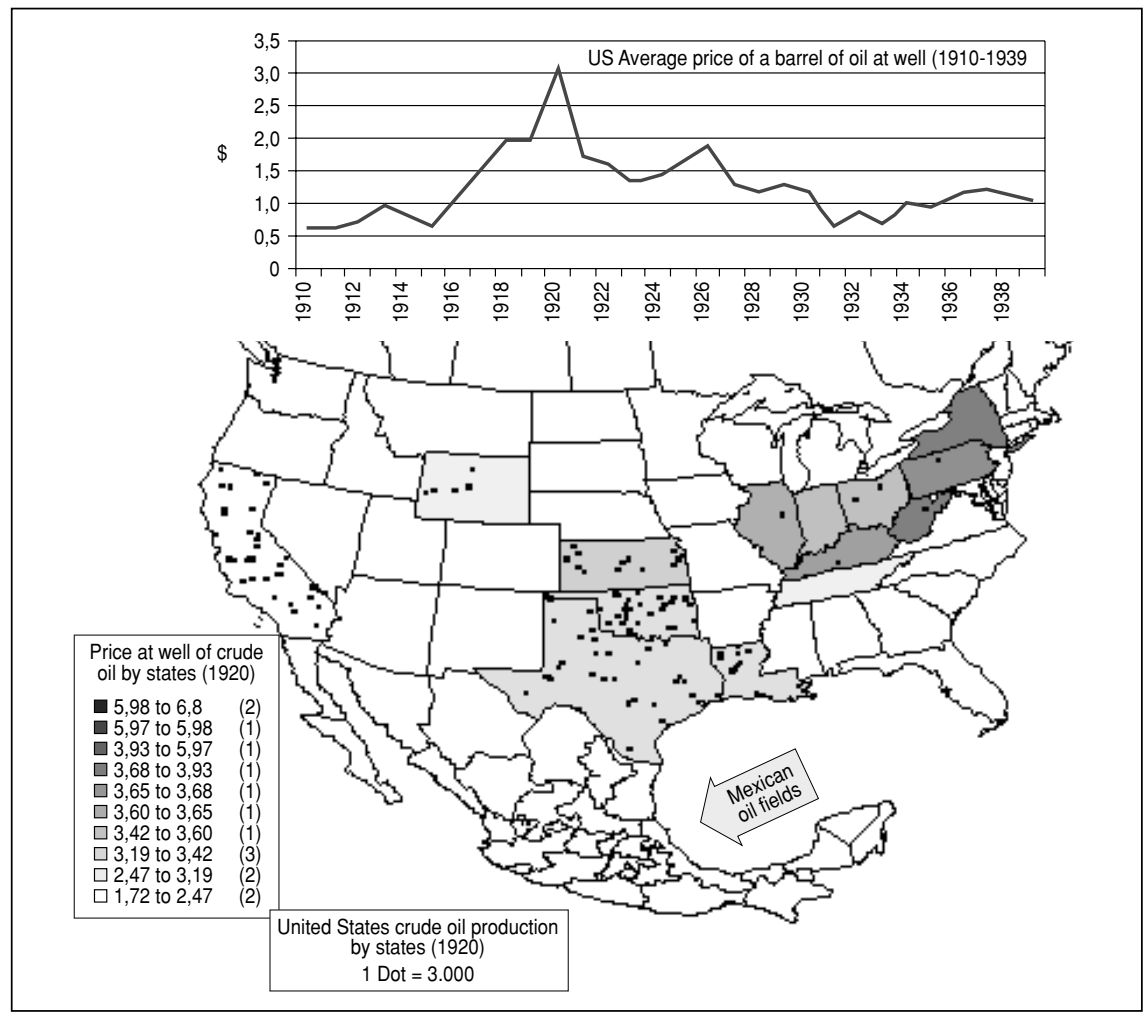

Sources: American Petroleum Institute (1937). Mexican oil prices in 1920 were between 0.92 and 1.0 US \$ per barrel according to the data in Appendix F in Rubio (2002).

Coast than on the West: in 1920 a barrel of oil in California cost $\$ 1.72$, while on the other side of the country, in the state of New York, the price was \$5.98. The location of oil production and the price gradient in the U.S. for 1920 are shown in Figure 8 .

Distance from the oil producing regions to U.S. consumers gave some cost advantage to foreign oil. The U.S. officials acknowledged the importance of foreign oil in supplying the American East coast in the reports on oil produced by the U.S. Department of Commerce (various years). It was more expensive to deliver domestically produced oil from California or the Mid Continent to the East Coast than Mexican oil. According to the calculations of the U.S. Tariff 
Commission (1932), the costs of production and delivery of domestic oil to the Atlantic seaboard refineries still exceeded those of Mexican oil at the end of the 1920s. The costs of putting domestic oil on the Atlantic seaboard were calculated at \$2.17 per barrel, while those of Mexican oil were estimated at \$1.44 in 1927. These figures include the costs of production, transportation (pipeline plus ocean tanker) and taxes. Given this framework it is very unlikely that the companies could lodge a credible threat to shut down production in Mexico in order to put pressure on the Mexican government by withdrawing vital oil taxes. If anything, the dependency was mutual in those years.

From this depiction it is clear that Mexican crude oil played the crucial role of supplying the U.S. at this period of shortage, while also allowing an uninterrupted supply to Europe. By focusing on events outside Mexico rather than inside the country it is easier to understand that the rise of the Mexican oil industry had a lot more to do with events on international petroleum markets than with mere «natural resources lottery» as has usually been maintained. Mexican oil fields were required to produce at maximum capacity during a period when world markets were in dire need of oil as a result of the combination of events described in the previous sections. Mexico, then, became the second largest petroleum producer in the world after the United States and the largest exporter of petroleum. This position was short-lived. Whether the fall of the industry was rooted in the particular characteristics of its rise is the issue addressed in the last section of this paper.

\section{THE END OF THE SHORTAGE AND THE END OF THE MEXICAN OIL SURGE}

It is certain that events within Mexico had an impact on the decline of the industry (namely the debate over subsoil rights following the 1917 Constitution; the various other decisions taken by successive Mexican governments - regulations, tax hikes, the creation of Federal reserves - the threat of arbitrary deprivation of vested rights; the increasing organisation of workers after the Revolution). Nevertheless, it is worth wondering whether events outside Mexican (and Venezuelan) territory also played a part in the decline alongside internal developments. Given the nature of the rise, it is logical to investigate the other side of the story in order to discover whether the end of the shortage and changes in international markets can shed some extra light onto the debate surrounding the rapid fall of this early Mexican industry.

Total petroleum output peaked in 1921 and exports of crude and derivatives peaked one year later. Traditional accounts of what followed normally describe the sudden slump suffered by the Mexican oil industry. A closer look at the Mexican data reveals a different timing. Only two factors peaked in the Mexican 
oil industry in 1921: the flow of investment into the industry (as will be seen in a moment) and the output and exports of light oil. Exports of fuel oil and natural gasoline peaked in 1922. Heavy oil output and exports reached maximum levels in 1924; exports of refined gasoline and crude kerosene in 1925; exports of asphalt in 1927 and those of gas-oil and lubricants in 1929. Finally, in 1930 more refined kerosene was exported from Mexico than ever before ${ }^{14}$.

In 1924 Mexico still produced 46 per cent of all the oil produced outside the U.S. Despite the decline in output through the 1920s, Mexico was still the main oil producer outside the U.S. until the end of the decade when Venezuela first (1928) and the Soviet Union later (1931) overtook her. Mexico continued to supply some of the major oil markets outside the U.S. such as the United Kingdom, Germany or Cuba as can be seen in Figure 9. Clearly Mexico did not suddenly become an insignificant oil producer but was still a major oil exporter until well into the 1930s as can be observed in Figures 4 and 5 above.

Part of the perception of a sudden decline of the Mexican industry stems from the fact that U.S. imports of Mexican oil did fall quite rapidly. By 1925 the U.S. imported from Mexico half the amount of crude oil imported in 1921, a fifth by 1927 and twenty times less by $1933^{15}$. It can be observed that the rapid fall of exports to the U.S. was not followed by an equal fall in exports to the other main destinations. Yet the assumption made by the U.S. analyst was that the rapid decline of U.S. imports from Mexico mirrored Mexican supply ability. From this premise, Mexico was thought to be running out of oil at least as fast as the U.S. imports from Mexico were declining. However, the reasons for the decline of U.S. imports of Mexican oil relate more to U.S. demand for foreign oil than to the supply of oil from Mexico.

U.S. demand for imports of petroleum products, which peaked with the postwar shortage in 1921, halved by 1927. Furthermore, by 1933 the U.S. imported a quarter of the total amount of crude oil imported in 1921. The reasons behind the reduction of crude imports into the U.S. lie not in the fact that Mexico was unable to supply sufficient oil (Mexico produced enough oil to satisfy the American demand until at least 1928) but rather in the changes in the supply of oil within the U.S. and elsewhere seen in Figures 4 and 7 above.

The fears of oil shortages of the early 1920s in the U.S. were replaced by an ever-growing surplus in the mid-1920s from the newly discovered fields in

${ }^{14}$ Sources for the Mexican exports by type of product: México, Secretaría de Hacienda y Crédito Público, Departamento de Impuestos Especiales, Sección de Petróleo (1936a) and Secretaría de Hacienda y Crédito Público, Departamento de Impuestos Especiales, Sección de Petróleo (1936b). The data on Mexican production by type of oil: Mexico, Secretaría de Hacienda y Crédito Público, Dirección General Técnica de Ingresos, Oficina de Investigaciones Económicas (1938), pp. 117-118.

15 The U.S. imported 125 million barrels of crude oil from Mexico in 1921, 26 million in 1927 and only 5.8 million barrels in 1933. Data from the American Petroleum Institute (1937), p. 208. 
FIGURE 9

MEXICAN EXPORTS OF CRUDE OIL AND DERIVATIVES BY MAIN COUNTRY OF DESTINATIÓN, 1920-1939

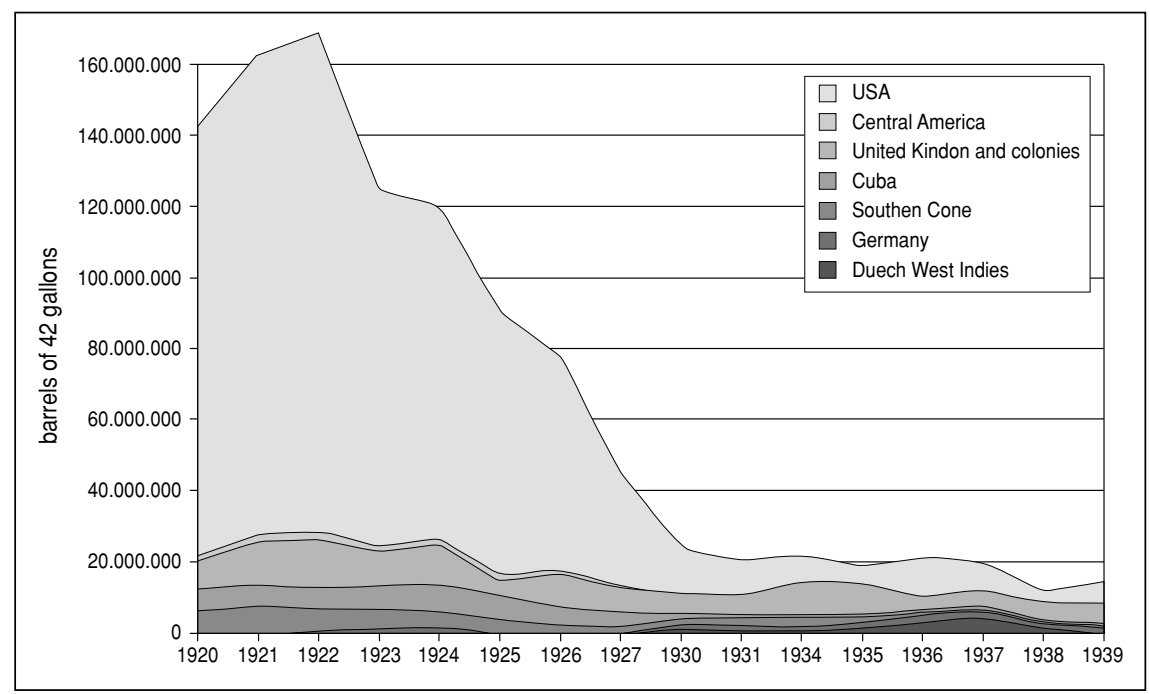

Sources and notes: Mexico. Departamento de la Estadística Nacional (various years). Central America includes Costa Rica, El Salvador, Honduras, Nicaragua and Panama. United Kingdom includes also the exports to British possessions such as Bahamas, Jamaica and British Honduras. Southern Cone refers to Argentina, Brazil, Chile and Uruguay.

California, Arkansas, Texas, Oklahoma and Louisiana, culminating in the huge main East Texas field in 1930. It is not mere coincidence that imports of oil into the U.S. declined as production gushed in California first (1923) and Oklahoma later (1927). In fact, inventories of crude oil in the U.S. kept growing: 300 million barrels by the end of 1922, over 400 million by 1924 and more than 500 million barrels just before the Great Depression. These levels are many times more than the inventory levels shown in Figure 6 above. As a consequence of the petroleum surplus within the U.S., prices maintained a declining trend for the rest of the decade as shown in Figure 8 above.

At world level, surging production in Venezuela and Persia, in addition to the return to production and exports of Russia (which began to take effect in 1924), plus the contribution of the new smaller producers of South America (Colombia, Peru, Ecuador and Trinidad), all contributed to a situation in which, for the first time since the beginning of the War, oil supply began to exceed demand from 1925 onwards.

The shortage ended, as did the crucial role played by Mexican oil as a supplier of the U.S. market. What did not end were the uncertainties in the world petro- 
leum industry. The scenario for a worldwide oil rush was set at the end of the War. Oil was sought out in more countries during the second half of 1920s than ever before. However, the nationalism awakened during the War regarding natural resources made it difficult for the companies to secure new exploration contracts and nothing could guarantee that previously signed agreements were to be honored, as noted in Section 2.

At the same time, the shortage of the early 1920s confronted the U.S. petroleum industry with a largely overlooked problem. The oilmen and the government alike suddenly realized that the sources of supply of the domestic industry were concentrated within its own borders and in Mexico. It was the time to launch an «aggressive American oil policy abroad» as noted by DeNovo (1956). This new policy, launched immediately after the end of the War, forced U.S. companies to seek out new supplies on a worldwide basis, either by exploration or by purchase of existing production, only to find out that the situation was not going to be that easy. It came as a bitter realization for U.S. oil companies to find that by the early 1920s, British companies which were currently turning out about 15 per cent of world production, had somehow acquired more than half the world's estimated future reserves thanks to the rights acquired by Royal Dutch-Shell and Anglo-Persian Oil Co. which held quasimonopolies in Venezuela, Persia, Dutch East Indies and British East and West Indies.

It is not heroic to presume that the uncertainties in the world petroleum industry had a negative impact on the Mexican oil industry. Not only had the U.S. lost interest in Mexican oil due to the simple fact of having found increasing domestic supplies, but U.S. industry also now had a new active policy for securing reserves elsewhere in the interests of diversifying its foreign supplies.

Haber et al. (2003) argued that the oil companies continued to explore and invest in Mexico well after output began to fall and left simply because they could not find more oil. The truth is that companies were searching for oil in Mexico with less intensity than elsewhere during the 1920s as can be deducted from the figures of U.S. exports of petroleum machinery and equipment shown in Table 1.

It is certainly true that the average flow of drilling investment into Mexico throughout the 1920s, although declining, was higher than that of the previous decade. Yet from the previous discussion it is also clear that the oil rush gathered pace all over the world after the War as did worldwide petroleum investment. Total exports of oil machinery and equipment from the U.S. more than doubled their value in real terms between 1922 and 1925 and by 1930 they were almost six times the value of 1922. As for drilling equipment, the crucial element for finding and extracting new reserves, the real value of U.S. exports trebled between 1922 and 1925 and doubled again by 1930. While Mexico received over a third of all drilling apparatus exported from the U.S. in 1922, the figure fell to 9 per cent in 1925 and 3.8 per cent in 1930. The flow of oil (well) drilling machinery into Mexico was clearly falling behind the growth of the oil industry worldwide. 


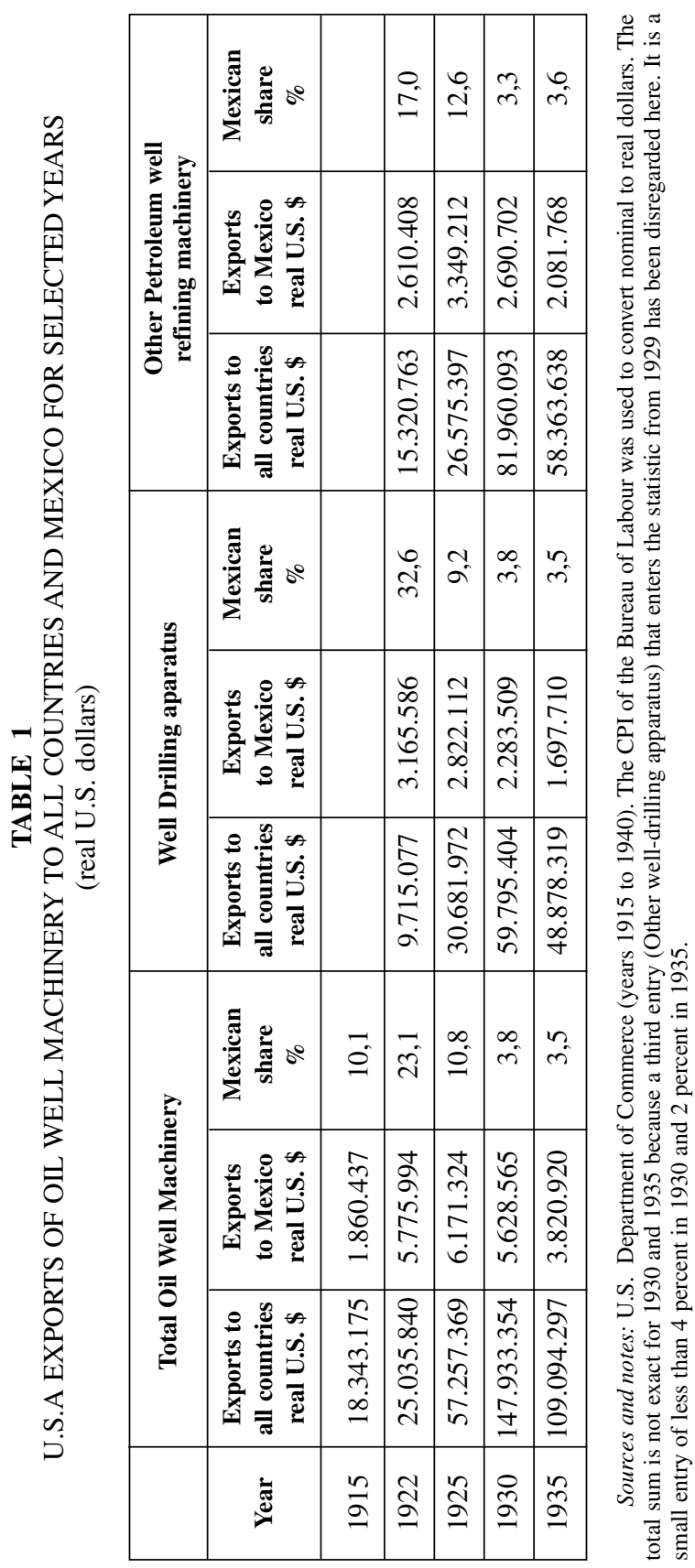


An alternative hypothesis for the reduced flow of investment into Mexico is that the decreasing production justified smaller investments than other activities, or as argued by the geological explanation of Haber et al. (2003), the companies «left Mexico when they could no longer find sources of petroleum that could be extracted at a reasonable price using existing technology» during the second half of the decade. However, the data presented above do not indicate that companies left Mexico in the second half of the 1920s, simply that they did not increase their investment at the same rate as elsewhere. Only at the time of the nationalization of the oil industry did Mexico reach the minimum investment flow of the whole period studied. The companies only left when their property was expropriated in 1938 .

Of course the blow out of Venezuela's oil fields in 1922 attracted immense amounts of oil drilling equipment to that country. Yet by 1924 both the British East Indies and Mexico were still receiving more drilling machinery of U.S. production than Venezuela according to the same data of the U.S. Department of Commerce (1915 to 1940). A year later, however, not only had Venezuela surpassed the level of new investments of Mexico, but so had the British East Indies, the Dutch East Indies and even Argentina. At the end of the decade the list of countries receiving more oil drilling machinery than Mexico also included the Soviet Union, Canada, Rumania, the British West Indies and Colombia, with Persia coming close to Mexican levels. Nevertheless, of the long list of countries receiving greater amounts of drilling equipment than Mexico, only two countries, Venezuela and the Soviet Union, produced more oil than Mexico in 1929. It is clear then that Mexico was losing out in comparison with the rates of new investment elsewhere in the industry.

The question of whether Mexico was running out of oil which could be extracted with the existing technology remains to be explored. There are few estimates of proven reserves in the 1920s but those available can be used to show that Mexico's proven reserves were not lower than those of the other oil producers of the time. White (1920), an engineer of the Foreign Mineral Section of the U. S. Geological Survey, estimated world reserves of the main petroleum countries in 1920. He estimated Mexican oil reserves were 4,525 million barrels, while Venezuela's were estimated at 105 million barrels in the same year. Even if no additional oil was found in Mexico in the following 20 years (which was not the case) and subtracting real cumulative production in the country, Mexican reserves in 1925 can be calculated at approximately 3,500 million barrels while Venezuelan reserves were said to be 500 million barrels. Even in 1935 Mexico's fields would hold a further 3,100 million barrels while Venezuela's proven reserves were estimated at 2,900 million ${ }^{16}$. Thus, at least in the 1920s Mexico's future as an oil producer looked as bright as that of its main competitor, Venezuela.

16 Venezuelan reserves for 1925 and 1935 from: United Nations, Economic Commission for Latin America (1960), p. 59. For 1919, 1924, 1929, 1934 and 1939: Martínez (1989), p. 166. 


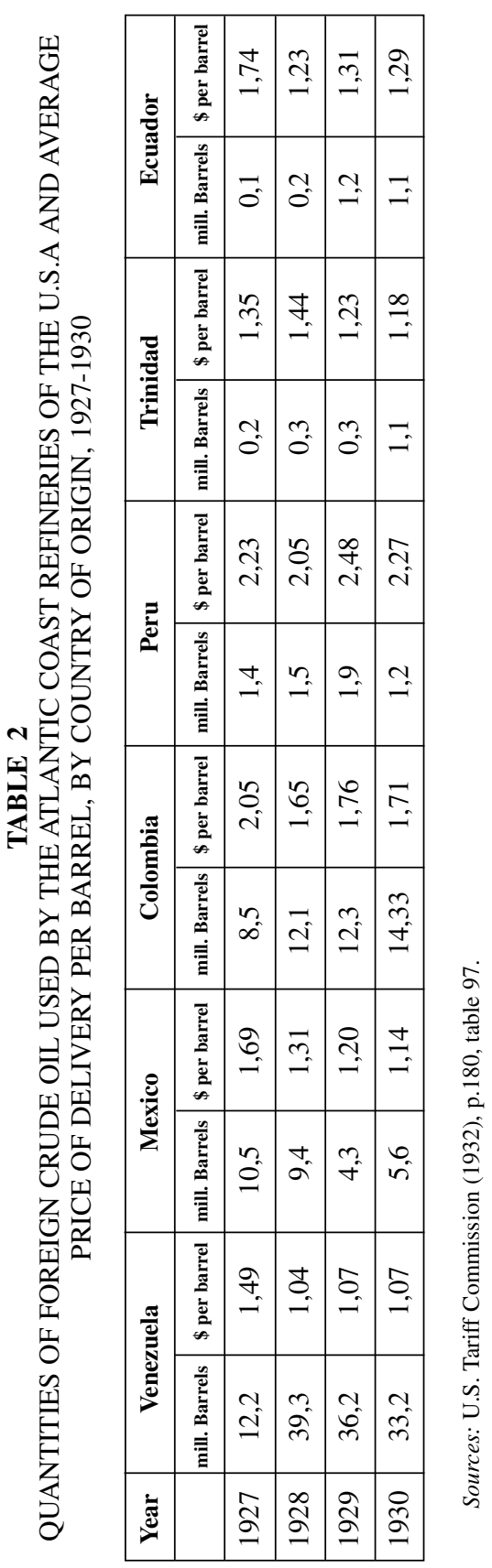


It can also be argued that petroleum discovered elsewhere was cheaper and of higher quality than Mexican oil and faced with greater competition, the Mexican oil industry was unable to survive. By the mid 1920s the U.S. started to import oil from countries other than Mexico (Venezuela, Colombia, Peru, Ecuador and Trinidad). The immediate question is whether these countries had any cost or quality advantage over Mexico. In this line, Table 2 reports the results of an enquiry by the U.S. Tariff Commission (1932). The results indicate that in fact, only Venezuelan oil was cheaper to import into the U.S. than Mexican oil, none of the other countries having any price advantage over Mexico. The report does not suggest that any of the competing countries had any quality advantage over Mexico at that time.

From the account in this section it seems that events in the industry at an international level affected the decline of the Mexican industry in several ways. The end of the shortage and the changes and uncertainties in the petroleum industry worldwide help provide a better understanding of the sudden decline of the Mexican industry, without precluding the domestic incidents signalled in the first section of this paper.

\section{CONCLUSIONS}

Thanks to the data of the American Petroleum Institute, the U.S. Department of Commerce and the Mexican Government this paper has placed the early Mexican oil industry within the changing context of world oil markets of the early 1920s. This brings an international perspective to the historiography which, to date, had concentrated heavily on events within Mexico and which had paid far more attention to the decline of the industry than to the reasons for its dramatic rise during the years of the First World War.

However intense the domestic challenges may have been, stepping outside Mexico has made it possible to show that these were related to the extensive changes taking place in the petroleum industry worldwide during the First World War and its aftermath. The fate of the Mexican oil industry in those years is easier to understand once the international perspective is taken into account. The surge in demand and the worldwide awakening of nationalism regarding the exploitation of petroleum resources would, in turn, have effects on the development of the petroleum industry in Mexico. The intense growth of demand for petroleum products in the world was not followed by an equal growth in supply. The distortions caused by the War, the Soviet Revolution, the cold winters of the end of the 1910s, plus the final War effort produced the first petroleum shortage of the 20th century between the years 1918 and 1921. The importance of Mexican oil at this time of shortage should not be underestimated as it was cru- 
cial for the U.S. markets and, via re-export, for European markets. Indeed, the shortage was at the root of the sudden rise of petroleum output in Mexico between 1918 and 1921. The shortage ended but uncertainty in the petroleum industry worldwide continued. The War and the shortage represent a watershed for the development of the oil industry, beginning the formation of the global structure which became the most important characteristic of the industry for the rest of the century. The end of the shortage meant that U.S. refineries were no longer so dependent on Mexican oil and the uncertainties and changes in the structure of the market contributed to the relegation of the Mexican oil industry to a secondary role when the new active policy for securing reserves elsewhere implied losing out in new investment.

The international perspective of this paper has made it possible to improve our comprehension of the initial rise of the Mexican oil industry and also that of its subsequent sudden decline.

\section{REFERENCES}

American Petroleum Institute (1937): Petroleum Facts and Figures. New York.

COlEGIO DE MÉXICO (1960): Estadísticas económicas del Porfiriato: comercio exterior de México, 1877-1911. México D.F.

Colegio de MéXico, Seminario de Historia Moderna de México (1965): Estadísticas económicas del Porfiriato: fuerza de trabajo y actividad económica por sectores. México D.F.

DARMSTADTER, J., and et al. (1971): Energy in the World Economy, A Statistical Review of Trends in Output, Trade and Consumption since 1925. London.

LLOYD's REGISTER OF SHIPPING. (s.d.): «World's fleet statistics».

México. Government of (1925): «Estadísticas del Petróleo». Estadística Nacional., Febrero 4, pp. 26.

MÉXICO. GovernMENT OF (1937 December): «Estadística Petrolera». Revista de Industria. Revista Mensual 1: 2, pp. 21.

México. Departamento de la Estadística Nacional (various years): Anuario estadístico, comercio exterior y navegación.

México. Instituto Nacional de Estadística, Geografía e Informática (INEGI). (1994): Estadísticas históricas de México. México D.F.

México. Secretaría de Hacienda y Crédito Público. Departamento de Impuestos EsPeCiales. SECCIÓn de Petróleo (1936a): Cuadros estadísticos del petróleo, 19251930. México D.F.

- (1936b): Cuadros estadísticos del petróleo, 1930-1935. México D.F.

México. Secretaría de Hacienda y Crédito Público. Dirección General Técnica de Ingresos. Oficina de Investigaciones Económicas (1938): La Industria del Petróleo en México. México, D.F.

México. Secretaría de Patrimonio Nacional (1963): El Petróleo de México. México D.F.: Goverment. 
NBER (2003): «Crude petroleum stocks, end of month. NBER SERIES: 05013». Macrohistory database: http://www.nber.org/databases/macrohistory/contents/chapter05.html.

PEMEX (Petróleos MeXicanos) (1952): Informes del Director General Senador Antonio J. Bermúdez 1947-1952. México D.F.

PEMEX (Petróleos Mexicanos) (ed.) (1988): La Industria Petrolera en México: una Crónica. México D.F.

U.S. DePartMENT OF COMMERCE (various years): Commerce Year Book. Washington D.C.: Government Printing Office.

- (years 1915 to 1940): Foreign Commerce and Navigation of the United States. Washington D.C.: Government Printing Office.

U.S. Department of Commerce (by J. R. Bradley) (1931): Fuel and Power in Latin America. Washington D.C.: Government Printing Office.

U.S. Department of Commerce (by W. A. Ottis) (1924): «The Petroleum Industry of Russia». Trade Information Bulletin. Supplement to Commerce Reports, No. 263.

U.S. Federal Trade Commission. (1923): Foreign Ownership in the Petroleum Industry. Washington D.C.: Government Printing Office.

U.S. TARIFF Commission. (1932): Production cost of petroleum products and of refined petroleum products. Washington, D.C.: Government Printing Office.

United Nations. ECONOMIC COMMISSION fOR LATIN AMERICA. (1960): «Economic Developments in Venezuela in the 1950s». Economic Bulletin for Latin America 1: 1, pp. 21-61.

\section{BIBLIOGRAPHY}

AdLeson, S. L. (1992): «The Cultural Roots of the Oil Workers' Unions in Tampico19101925 '», in J. C. BRown, and A. KNIGHT (eds.), The Mexican Petroleum Industry in the Twentieth Century. Austin: University of Texas Press.

Baldridge, D. C. (1987): Mexican Petroleum and the United States-Mexican relations, 1919-1923. London.

Bermudez, A. J. (1963): The Mexican National Petroleum Industry: A case study in Nationalisation. Stanford.

Brown, J. C. (1985): «Why Foreign Oil Companies Shifted Production from Mexico to Venezuela during the 1920s». American Historical Review 90, pp. 362-385.

- (1993): Oil and Revolution in Mexico. Oxford: University of California Press.

CÁRDEnAs, E. (comp.) (1992-1994): Historia Económica de México (5 vols.). México, D.F.

De Novo, J. A. (1956): «The Movement for an Aggressive American Oil Policy Abroad, 1918-1920». The American Historical Review 61: 4, pp. 854-876.

Grayson, G. (1980): The Politics of Mexican Oil. Pittsburgh.

Haber, S.; Mauer, N., and Razo, A. (2003): «When Law Does Not Matter: The Rise and Decline of the Mexican Oil Industry». Journal of Economic History 63: 1, pp. 1-32.

HABER, S. H. (1989): Industry and Underdevelopment. The Industrialisation of Mexico, 1890-1940. Stanford.

Haber, S. H.; MaUer, N., and Razo, A. (no published): «When Institutions do not Matter: The Rise and Decline of the Mexican Oil Industry». Paper presented at the Economic History Seminar at UC Berkeley, September 2001. 
KNIGHT, A. (1992): «The Political Economy of Revolutionary Mexico, 1900-1940», in C. ABEL, and C. M. LEwIS (eds.), Latin America, Economic Imperialism and the State: The Political Economy of The External Connection form Independence to the Present. London, pp. 288-366.

LóPez Portillo, J. (1938): «Las Reservas Petroleras Mexicanas». Revista de Economía (Revista de Economía) II: 7-12, pp. 475-485.

- (1975): El petróleo de México. México D.F.

Manterola, M. (1937): «La Situación de la Industria del Petróleo en México y su Reciente Nacionalización». Revista de Economía (Revista de Economía) I: 1-6, pp. 361-377.

MARTíneZ, A. R. (1989): «El papel de la explotación petrolera en el proceso de modernización de la sociedad venezolana y la perspectiva inmediata», in Francisco MIERES (ed.), Hacia la Venezuela Post-petrolera (conference sponsored by la Academia Nacional de las Ciencias Económicas in 1985). Caracas: Academia Nacional de Economía, pp. 151-177.

MenÉndez, G. A. (1958): Doheny, el cruel. México D.F.

Novelo, V. (1991): La difícil democracia de los petroleros. México, D.F.

Owen, E. W. (1975): Trek of the Oil Finders: A History of Exploration for Petroleum. Oklahoma.

PhILIP, G. (1982): Oil And Politics In Latin America. Nationalist Movements And State Companies. Cambridge.

RAmírez Heredia, R. (1979): La otra cara del petróleo. México, D.F.

REYNOLDS, C. W. (1970): The Mexican Economy. Twentieth-Century Structure and Growth. London.

RIPPY, M. (1972): Oil and The Mexican Revolution. Leiden.

Rubio VARAs, M. M. (2002): «Towards Environmental Historical National Accounts for Oil Producers: Methodological Considerations and Estimates for Venezuela and Mexico over the $20^{\text {th }}$ Century». London: PhD Thesis, London School of Economics.

Sangines Villavalva, E. (1938 Marzo): «La industria petrolera en México». Revista de Hacienda (Revista de Hacienda) II.

Silva Herzog, J. (1938): «La expropiación de las compañías petroleras en México». Revista de Economía (Revista de Economía) II: 7-12, pp. 447-457.

THORP, R. (1989): «Economy, 1914-1929», in L. BETHELL (ed.), Latin America Economy and Society 1870-1930. Cambridge, pp. 57-82.

ThORP, R. (1998): Progress, Poverty and Exclusion. An Economic History of Latin America in the $20^{\text {th }}$ Century. New York: Inter-American Development Bank.

White, D. (1920): «The Petroleum Resources of the World». Annals of the American Academy.

Wilkie, J. W. (1967): The Mexican Revolution: Federal Expenditure and Social Change since 1910. Berkeley: University of California press.

Wilkins, M. (1974): «Multinational Oil Companies in South America in the 1920s: Argentina, Bolivia, Brazil, Chile, Colombia, Ecuador and Peru». Business History Review 48: 3, pp. 414-446.

YeRgIN, D. (1991): The price: the epic quest for oil, money and power. New York: Simon \& Schuster. 